\title{
Florestan Fernandes: uma voz imprescindível
}

\section{LUIZ DE SOUSA JUNIOR}

Neste ano de 2018 completam-se 30 anos da atual Constituição Federal (CF) da República Federativa do Brasil, promulgada em 5 de outubro de 1988. Ocorre que, desde então, já foram aprovadas 95 Emendas Constitucionais até a presente data, as quais desfiguraram quase completamente os objetivos e alcance do texto original. Com efeito, a CF de 1988 apontava para a construção de um Estado de Bem-Estar Social, nos moldes dos países europeus, pós-segunda guerra mundial, e de ampliação dos direitos da cidadania. Tal perspectiva foi bombardeada desde os primeiros anos de vigência da CF, a pretexto da "modernização" do Estado, que nada mais era do que a promoção do downsiz̨ing dos direitos sociais. Apenas um breve período, de mais ou menos dez anos, entre 2004 e 2014, foi de expansão do Estado Social, sem, contudo, alterar a estrutura de acumulação de capital. Mesmo assim, cobra-se, hoje, esse "insulto" cometido contra as forças tradicionais locais e transnacionais, exigindo-se, por exemplo, o retorno do investimento em políticas sociais ao patamar que fora praticado há 30 anos.

A educação sofrerá fortemente os impactos dessa política regressiva. Até porque, com relação ao desmonte da Constituição Federal, a área tinha sido poupada de grandes cortes. Num certo sentido, as emendas constitucionais aprovadas com relação ao capítulo da Educação, se não significaram maior aporte de recursos, ao menos não implicaram redução dos percentuais investidos. ${ }^{1}$ Isso foi alterado tragicamente com a aprovação da Emenda Constitucional 95/2016, visto que, de forma concreta, essa Emenda desvincula os recursos constitucionalmente direcionados para as áreas de educação e saúde nos próximos 20 anos.

A luta pela vinculação de percentuais de recursos de impostos para a educação foi um dos principais embates que se deu na Assembleia Nacional Constituinte (ANC) de 1986-1988 e teve em Florestan Fernandes, deputado constituinte pelo Partido dos Trabalhadores (PT), um dos seus maiores defensores.

\footnotetext{
1 Note-se que a promulgação da Emenda Constitucional 59/2009 sinalizou para ampliação do investimento na Educação Básica. A Lei12.858/2013, que trata da distribuição dos recursos do petróleo e gás natural para saúde e educação, e a Lei 13.005/2014, que aprovou o Plano Nacional de Educação, na esteira desse movimento de incremento de recursos para o setor, também apontavam para o aumento de recursos para a educação pública.
} 
Tive a honra e felicidade de poder conversar com o deputado Florestan Fernandes acerca do processo constituinte de 1986-1988. A entrevista aconteceu em virtude de pesquisa que desenvolvi, no início dos anos de 1990. Julguei fundamental escutá-lo sobre o projeto de construção do projeto de educação do PT e o diálogo ocorrido entre os diversos partidos no interior da própria ANC, para fins de conclusão de minha dissertação de mestrado. ${ }^{2}$ Foi a única entrevista utilizada na dissertação.

Florestan Fernandes deixou um legado incomensurável para a sociologia, em geral, e para a educação brasileira, em particular. É considerado o fundador da sociologia crítica no Brasil. Sua vasta produção nos permite conhecer muito da estrutura social brasileira, suas desigualdades e contradições. Seus estudos de mestrado, doutorado e livre docência abordaram, respectivamente, os seguintes temas: A organização social da sociedade Tupinambá”, "A função social da guerra na sociedade Tupinambá" e "Ensaio sobre o método de interpretação funcionalista na sociologia". Como catedrático escreveu "A integração do negro na sociedade de classes". Foi professor da Universidade de São Paulo - onde foi aposentado, compulsoriamente, pelo regime militar - da Columbia University, da Universidade de Toronto, da Universidade de Yale e da Pontifícia Universidade Católica (PUC) de São Paulo. Em 1975, lança um dos seus clássicos, "A revolução burguesa no Brasil", mudando radicalmente a interpretação acerca do desenvolvimento do capitalismo no Brasil. Para Octavio Ianni (2015), o segredo do pensamento de Florestan Fernandes se encontra justamente no fato de que "ele se constrói a partir da perspectiva dos grupos e classes sociais que compõem o povo propriamente dito, os trabalhadores da cidade e do campo" (p. 70).

No campo da educação salta à vista sua defesa intransigente do ensino público, como o fez na campanha em defesa da escola pública, no final dos anos de 1960, e que foi retomada na sua participação na ANC de 1986-1988. Tratava-se de uma postura altiva, a qual Dermeval Saviani sintetizou em quatro aspectos:

2 A pesquisa foi concluída sob orientação da professora Luzete Adelaide Pereira, em 1994, que veio a substituir meu primeiro orientador, professor Silvio Frank Alem, já bastante enfermo, na ocasião, e que viria a falecer em dezembro de 1993. O estudo seria defendido - e aprovado - junto ao então Curso de Mestrado em Educação, atualmente Programa de Pós-Graduação em Educação (PPGE) do Centro de Educação da Universidade Federal da Paraíba (UFPB). A banca examinadora foi composta pelas seguintes pesquisadoras: Luzete Adelaide Pereira (orientadora), Maria de Lourdes Barreto e Sofia Lerche Vieira. 
O primeiro aspecto enfoca a figura do professor Florestan, evidenciando o profundo significado educativo que marcou o seu magistério. O segundo aspecto destaca o lugar ocupado pela educação nas investigações científicas por ele realizadas. O terceiro refere-se ao seu engajamento na luta em defesa da educação pública, desde a campanha em defesa da escola pública até a sua atuação como deputado federal. Finalmente, o quarto aspecto coloca em evidência o publicista incansável, empenhado em divulgar sob todas as formas a seu alcance, a causa da defesa de uma escola pública de qualidade acessível a todos os brasileiros (SAVIANI, 1996)

A entrevista que se segue tratou, exatamente, da atuação de Florestan tanto na condição de parlamentar quanto de publicista da causa educacional. Em perspectiva, ressalta-se que a militância de Florestan, seja como educador/ pesquisador seja, posteriormente, como parlamentar, continua como referência para as forças democráticas e populares do país, que almejavam um país mais inclusivo e mais justo. Ela me foi concedida, finalmente, em 23 de setembro de 1993. Conforme já fiz referência, foi a única entrevista que utilizei no estudo, que versava sobre o projeto de educação do PT na ANC de 1986-1988. A grandeza da figura de Florestan justifica essa decisão. Mas o fato é que até a presente data, esta entrevista não foi dada a conhecimento público em sua integralidade.

O encontro ocorreu no próprio gabinete de Florestan, na Câmara dos Deputados, em Brasília. A agenda atribulada do parlamentar foi um obstáculo para sua imediata realização e, por conta disso, acabou por acontecer antes do início de uma sessão da Comissão de Educação, da qual fazia parte. Mesmo assim, com a gentileza e humildade que marcaram a personalidade do maior dos sociólogos brasileiros, Florestan, com voz pausada e num tom muito baixo, já denunciando a idade avançada e seus problemas de saúde, respondeu prontamente a todas as perguntas. Isso não o impedia de, a cada 15 ou 20 minutos, solicitar a um dos seus assessores verificar se a sessão estava por se iniciar. Naquele dia, felizmente para mim, a sessão não deu quórum.

O ano de 1993 transcorria sob o manto de uma revisão constitucional que, ao final das contas, seria um enorme fiasco em razão das expectativas iniciais. Foram poucas alterações no texto original aprovado em 1988. Apenas seis Emendas Constitucionais de Revisão foram aprovadas, sendo as mais importantes foram a que criou o Fundo Social de Emergências e a que alterou o tempo do mandato presidencial de cinco para quatro anos.

O período que se sucedera à promulgação da Constituição Federal de 1988 fora de muita instabilidade política e econômica, com o impeachment do primeiro presidente eleito pós-Ditadura Militar, Fernando Collor de Melo, acusado de corrupção, que implantara um fracassado plano de estabilidade da economia. Seu sucessor, Itamar Franco, embora não tenha gozado de forte apoio 
parlamentar, obteve sucesso na economia com o chamado Plano Real, resultando, em seguida, na eleição de 1994 do seu então ministro da Fazenda, Fernando Henrique Cardoso, para presidente da República.

Florestan participara de todo o processo constituinte. Eleito pelo estado de São Paulo e compondo uma minúscula bancada de 16 parlamentares do PT, destacou-se por sua atuação em defesa da escola pública, estatal e gratuita e se tornou o principal interlocutor das forças progressistas acerca do tema. Marxista convicto e profundo conhecedor da sociedade brasileira, sua voz se fez respeitada, mesmo estando em franca minoria. E isso, por certo, fez toda a diferença.

Nesta entrevista procurei ouvir o parlamentar petista, inicialmente, acerca da construção do projeto de educação que o PT levaria para o debate na ANC, desde os primeiros escritos sobre o tema e os debates entre as diversas alas do partido sobre os desafios para a construção de uma educação pública e de qualidade. Florestan chama a atenção de, pelo menos, duas divergências basilares que marcaram esses debates no interior do Partido, as quais têm a ver com a posição de membros da Igreja católica: a primeira dizia respeito à questão da exclusividade ${ }^{3}$ dos recursos do governo para o ensino público. Essa posição tornouse vencedora depois de uma discussão acirrada, segundo Florestan, por conta do voto de minerva de Lula e com provável apoio dos militantes das comunidades eclesiais de base que participavam do PT. Um outro ponto discordante se deu com relação ao tema do aborto. Nesse tema, os católicos não abriram mão por se tratar de um dogma da sua fé. Acabou por prevalecer uma solução intermediária, assim descrita por Florestan: "nas questões sem consenso deveria haver tolerância para com os divergentes". Tais decisões contribuíram para que que parlamentares que estavam ensaiando um abandono do PT, já naquela época, a exemplo de Plínio de Arruda Sampaio, adiassem esse desfecho. ${ }^{4}$

No plano da ação parlamentar, Florestan narra como buscou sair do isolamento nos debates constitucionais, utilizando uma "tática de superação de obstáculos", como viria a denominar essa postura de buscar diálogos com outras forças políticas. Narra ainda como setores da Igreja Católica fizeram poderosos lobbies para favorecer a iniciativa privada com a abertura para o financiamento público de suas escolas.

Antes, porém, o deputado constituinte nos fez trilhar pela história da educação brasileira, numa deliciosa síntese sobre o que chamou de pensamento pedagógico de esquerda. Nessa breve digressão sobre a atuação da esquerda

\footnotetext{
3 Na entrevista, Florestan denomina de prioridade, porém, a proposta apresentada pelo PT tratava de exclusividade.

4 Plínio de Arruda Sampaio e outros militantes vieram a se desligar do PT, efetivamente, no ano de 2005, não necessariamente por conta dos motivos apontados por Florestan Fernandes nesta entrevista.
} 
parlamentar em defesa da educação pública, desponta o intelectual firme em suas posições de princípios, mas atento às circunstâncias daquele momento e do espaço restrito de atuação, bem como da correlação de forças, claramente desfavorável, que obrigava esses parlamentares a esquadrinhar negociações para além até dos projetos partidários. Tal flexibilidade, diria Florestan, constituir-se-ia em "uma espécie de oportunismo construtivo", em que se buscava obter algum ganho, evitando uma derrota total, e permitindo acúmulo de forças para buscar novos avanços.

Ao final dos trabalhos da ANC e, em que pese o debate aberto sobre a assinatura ou não do texto constitucional - quando setores da esquerda do PT propuseram pura e simplesmente rejeitar in totum o resultado final da Constituinte, posição que não prevaleceu - a nova Constituição Federal inauguraria um período em que, entre saltos e sobressaltos da História, caminharia no sentido de construção de um Estado de cidadania social, que estaria a se findar com o golpe jurídico-midiático que depôs a presidenta legitimamente eleita, Dilma Rousseff, abreviando, não se sabe se de forma definitiva, o ciclo de hegemonia eleitoral do PT, iniciado em 2003, com a vitória de Luiz Inácio Lula da Silva.

Florestan Fernandes veio a falecer em 10 de agosto de 1995, dois anos após me ter concedido esta entrevista, em razão de um transplante de fígado malsucedido, realizado no Hospital das Clínicas de São Paulo, e como resultado de um possível erro médico quanto ao procedimento. ${ }^{5}$

A entrevista foi essencial para a consecução dos objetivos de minha dissertação, mas, por diversos motivos, fui adiando sua publicação na íntegra. ${ }^{6}$ Quase um quarto de século depois, eis que surgiu a oportunidade de dar conhecimento público dessa contribuição de Florestan Fernandes ao debate acerca dos rumos da educação brasileira. Com efeito, o grave momento político atual, resultante do aprofundamento das medidas de exceção, ataque aos movimentos sociais, particularmente o do magistério, assassinato de lideranças populares, ${ }^{7}$ além dos cortes de gastos públicos, que praticamente inviabilizam a

\footnotetext{
5 Em tocante artigo no Jornal Folha de são Paulo, o jornalista Florestan Fernandes Junior (2015) narra o calvário de seu pai, que resultou no seu falecimento. O artigo está disponível para conhecimento público (na FSP, apenas para assinantes), em diversos ambientes virtuais, a exemplo do sítio do blog Viomundo por meio do link: http://www.viomundo.com.br/denuncias/137176.html.
}

6 A dissertação foi publicada na forma de livro, em 1998, mas sem a íntegra da entrevista. A esse respeito, ver SOUSA JUNIOR (1998).

$7 \quad$ No período posterior ao golpe de 2015, e até mesmo um pouco antes, o Brasil assistiu ao assassinato de 24 lideranças populares, entre elas a vereadora Marielle Franco, quinta mais votada do município do Rio de Janeiro; professores serem repremidos quando em defesa dos seus planos de cargo, carreira e remuneração, caso do município de São Paulo, na gestão de João Doria, e; por fim, intervenção militar no Estado do Rio de janeiro. 
Ciência \& Tecnologia em nosso país, põe em risco as poucas conquistas obtidas na Constituição de 1988, sobretudo quanto ao capítulo da educação, pelas quais Florestan tanto se bateu até seu último sopro de vida.

Como intelectual orgânico que o foi, a voz de Florestan Fernandes precisa ecoar em nossos corações e mentes. Ele, indubitavelmente, está na categoria dos grandes vultos da humanidade que o poeta Bertold Brecht definiria como os imprescindíveis.

Quero, por fim, deixar meus agradecimentos à família de Florestan Fernandes, na pessoa do seu filho, jornalista Florestan Fernandes Junior, pela gentileza de autorizar a publicação desta entrevista inédita.

\section{REFERÊNCIAS}

BRASIL. Emenda Constitucional No 95, de 15 de dezembro de 2016. Altera o Ato das Disposições Constitucionais Transitórias, para instituir o Novo Regime Fiscal, e dá outras providências. Diário Oficial da União, 2016.

BRASIL. Lei 12.858, de 9 de setembro de 2013. Dispõe sobre a destinação para as áreas de educação e saúde de parcela da participação no resultado ou da compensação financeira pela exploração de petróleo e gás natural, com a finalidade de cumprimento da meta prevista no inciso VI do caput do art. $214 \mathrm{e}$ no art. 196 da Constituição Federal; altera a Lei no 7.990, de 28 de dezembro de 1989; e dá outras providências. Diário Oficial da União, 2013.

BRASIL. Lei 13.005, de 25 de junho de 2014. Aprova o Plano Nacional de Educação - PNE e dá outras providências. Diário Oficial da União, 2014.

FERNANDES JUNIOR, Florestan. O adeus em um olhar: a vida e a morte de Florestan Fernandes. Folha de São Paulo. Caderno Ilustríssima, 20.10.2015. Disponível (para assinantes) em http://m.folha.uol.com.br/ ilustrissima/2015/10/1699583-o-adeus-em-um-olhar-a-vida-e-a-morte-deflorestan-fernandes.shtml. Acesso em 20/11/2016.

IANNI, Octavio. Florestan Fernandes e a formação da sociologia brasileira. In: IANNI, Octavio (Org,). Florestan Fernandes: sociologia crítica e militante. $2^{\mathrm{a}}$ ed. São Paulo: Expressão Popular, 2011, p. 15-72. 
SAVIANI, Dermeval. Florestan Fernandes e a educação. Estudos Avançados. vol. 10, n. 26. São Paulo Jan./Abr. 1996. Disponível em http://www.scielo.br/ scielo.php?script=sci_arttext\&pid=S0103-40141996000100013. Acesso em $18 \mathrm{de}$ outubro de 2017.

SOUSA JUNIOR, Luiz de. Educação e Política: o projeto de educação do Partido dos Trabalhadores e a Constituinte de 1988. João Pessoa-PB: Editora Universitária, UFPB, 1998. 162 p.

LUIZ DE SOUSA JUNIOR possui graduação em Ciências Econômicas pela Universidade Federal da Paraíba (1988), mestrado em Educação pela Universidade Federal da Paraíba (1994) e doutorado em Educação pela Universidade de São Paulo (2003). Atualmente é professor Associado da Universidade Federal da Paraíba. E-mail: luizsjunior@gmail.com 


\section{ENTREVISTA INÉDITA COM FLORESTAN FERNANDES}

Luiz de Sousa Junior: Bem professor, como o senhor sabe, a dissertação vai versar sobre o Partido dos Trabalhadores, o projeto de educação do partido com foco da Assembleia Nacional Constituinte. Eu gostaria de começar pelo fim. É mais ou menos o seguinte: Como o senhor avalia, hoje, o resultado dos debates constitucionais sobre o capitulo da educação na Constituinte de 1988? O senhor acha que foi positivo, foi um resultado além ou aquém do esperado pelo PT?

Florestan Fernandes: Bem, o PT não tinha programa ou projeto na área da educação. Esse projeto foi construído, não bem um projeto, mas um conjunto de ideias, tomadas de posição, isso tudo foi construído pelos professores petistas, posteriormente. É um órgão muito ativo, pelo menos pelo o que eu conheço em São Paulo, é um núcleo muito ativo dentro do PT. E cada acumulação de experiência nas várias áreas do ensino na cidade de São Paulo... os professores que tendem a ir para o PT são inconformistas, tem uma boa experiência prática e uma boa base teórica. Então, o projeto veio depois da elaboração da Constituição. Se você pegar...você deve ter, não tem o projeto de eleição do PT?...você vai ver que a área de educação ali é muito pobre e não condiz com a impregnação popular e socialista do partido. Isso se deve à origem inicial técnica, que foi constitucionalista, elaborada pelo professor (Fábio Konder) Comparato, que teve que aderir ao projeto. Houve um grupo, do qual participavam Plinio de Arruda Sampaio, eu, José Genoíno, Marco Aurélio Garcia. Nós andamos discutindo pontos da futura Constituição, e aí houve uma primeira inclusão de posições do PT em relação à Constituição e sua elaboração. E, posteriormente, nós tivemos ganhos no setor em Cajamar. E aí, já com maior número de quadros e militantes, pegamos ponto por ponto, os quais foram questionados. Não foram todas as questões, mas aquelas que foram questionadas.

\section{Luiz de Sousa Junior: Essa foi a reunião do Diretório Nacional?}

Florestan Fernandes: Essa reunião teve uma abrangência que ia de deputados, quadros, diretoria, as bases e naturalmente, membros dos diversos órgãos diretivos. Nessa reunião foram discutidos pontos que exprimiam minha posição também, através de concessões mútuas na área do que deveria ser a social democracia, o socialismo, comunismo. E, também, concessões mútuas naquilo que dizia respeito às posições dogmáticas de grupos e correntes. Vou dar dois exemplos: a questão da prioridade dos recursos do governo para o ensino público acabou 
ganhando por voto de Minerva do Lula. E quer dizer que o setor católico admitiu esse avanço. Agora, a questão por exemplo, do parto provocado, na questão do aborto, ocorreu uma disputa mais acirrada, porque os católicos não podiam abrir não de um dogma da sua fé. Houve várias tentativas de acomodação, não deram certo e se formou uma comissão especial que retirou uma diretriz: nas questões sem consenso deveria haver tolerância para com os divergentes.

\section{Luiz de Sousa Junior: Isso faz parte do Estatuto do PT, não é?}

Florestan Fernandes: É. E a inconsequência de militantes como Plínio Arruda Sampaio e outros que estavam ameaçando sair do PT e vieram a rever a posição e desenvolveram um comportamento conciliador. Agora, na área da educação, o nosso projeto é reconhecidamente pobre. $\mathrm{O}$ nosso projeto tem pontos avançados, mas dentro de uma perspectiva puramente na classe trabalhadora, interesses e ideologias dos trabalhadores, do socialismo, das transformações da sociedade brasileira, o projeto ficou aquém das exigências, o projeto do partido. E, por isso, quando eu era o responsável pelo setor da educação do PT, me reuni com alguns deputados que eram de esquerda e centro esquerda, firmamos uma espécie de bloco, tivemos a ideia de fundar, de constituir uma base de defesa externa. Porque, nós sabíamos que o embate com os conservadores iria ser muito forte entre os parlamentares. Então nós precisávamos de apoio e que não íamos nos encontrar entre os parlamentares que tinham posições contrárias às nossas. Então, nós formamos um grupo que acabou desembocando no Fórum Nacional em Defesa da Escola Pública.

\section{Luiz de Sousa Junior: Octávio Elísio, Hermes Zaneti...}

Florestan Fernandes: É, Zaneti, e tinha mais alguns padrinhos e elementos. Havia também até pessoas que só trabalharam naquela ocasião porque não tinham posição de esquerda, mas como eram educadores, eles tinham um avanço doutrinário no domínio da pedagogia que os impelia de ir além da média do pensamento conservador brasileiro que é muito atrasada nesse ponto, essa média é atrasada. E o eixo da nossa influência teve o fato de que eu e Octavio Elísio elaboramos vários projetos para dividir com colegas que eram professores e em troca tínhamos o apoio para nossos projetos. 


\section{Luiz de Sousa Junior: Ampliava a frente?}

Florestan Fernandes: Ampliávamos a frente. E graças a isso, alguns dos nossos projetos têm a proposição inicial de pessoas que apenas estavam de acordo com o que se pretendia e assinavam.

\section{Luiz de Sousa Junior: Uma tática?}

Florestan Fernandes: Uma tática de superação dos obstáculos. E, ainda assim, ela não deu os resultados que nós pretendíamos, claro, no Plenário... porque antes havia as subcomissões, as comissões e comissão de sistematização e o Plenário. $\mathrm{E}$ os conservadores de vários partidos tinham vínculos muito estreitos com as posições ideológicas de natureza confessional ou posições que eram capitalistas, do lobby ensino remunerado. Os lobbies atuavam de uma maneira muito forte. A igreja católica, em muitos pontos, não desenvolveu qualquer ajustamento conosco. Ela atuou de uma maneira muito rigorosa, de maneira vertical, tradicionalista. Esse pessoal teve uma influência em boa parte [da] Assembleia Constituinte, padres, freiras, principalmente freiras. O próprio Dom Luciano Mendes esteve presente em alguns debates defendendo as posições dela.

\section{Luiz de Sousa Junior: O senhor chegou a denunciar e recebeu pressões através de telegramas?}

Florestan Fernandes: Ah, todos receberam.

\section{Luiz de Sousa Junior: ...da Igreja, da alta hierarquia.}

Florestan Fernandes: Mas é preciso distinguir a Teologia da Libertação; foi muito coerente. Eu, por exemplo, por questões pessoais, quando voltei do Canadá, durante dois anos ficaria totalmente incomunicável na sociedade brasileira se não fosse $[\mathrm{m}]$ os companheiros, antigos alunos, aqueles colegas, jovens de correntes políticas que eram chegadas à Igreja católica. Eram esquerdistas, alguns até bem revolucionários e tinham meios de promover minhas atividades externas, semilegais, que era um tipo de nível de ensino. E note: esse setor teve muita coerência e eu estive muito preocupado na ocasião com a posições que eu tinha que defender e falei com um dos principais membros desse movimento de jovens da Igreja Católica, se eles ficariam constrangidos com a minhas posições, e disseram: "Então, está bom professor, o senhor tem plena liberdade, nós compreendemos quais são as suas posições e respeitamos. O senhor pode agir sem nenhum tipo de 
preocupação". Quer dizer, eu estava com o meu caminho livre dentro da Igreja Católica entre aqueles que cooperaram mais comigo tanto antes quanto depois da saída do Brasil.

Luiz de Sousa Junior: Professor, agora voltando um pouco à questão dos projetos do PT na educação. O PT primeiro apresenta um projeto de Fábio Konder Comparato. Esse projeto depois evoluiu para uma outra proposta que foi essa, que digamos assim, fechada nessa reunião em Cajamar.

Florestan Fernandes: Agora, eu tenho que dizer uma coisa do ponto de vista técnico, desde que a influência do PT não foi especificamente socialista, houve um empobrecimento do projeto em construção. O projeto Comparato, tecnicamente era melhor do que o projeto que nós defendemos, isso em técnica legislativa. Agora, na prática, o PT tinha também que dar respostas às exigências do movimento sindical, para as classes trabalhadoras e os movimentos sociais que são fortes no PT. E que cresceram muito depois da Constituinte, mas que já tinham força anteriormente e o PT tinha que assumir essas posições e avançar. Agora, o partido não se isolou na defesa de posições fechadas. O partido procurou posições reformistas, mas que na situação brasileira representavam um avanço para criar as condições de um aprofundamento das reformas e das mudanças. Quer dizer, uma posição reformista que tinha um embasamento mais largo.

\section{Luiz de Sousa Junior: O professor Moacir Gadotti, na ANPED (Associação Nacional de Pós-Graduação e Pesquisa em Educação) de 1986, ele apresentou uma proposta de educação do PT.}

Florestan Fernandes: É. Agora, a posição dele é uma posição que diz respeito a defesa de algumas pessoas do partido. E também dizem respeito a posições muito pessoais. Nem todos os militantes do PT estavam dispostos a rezar por essa cartilha; há uma concepção de educação que tinha vínculos com as acomodações do socialismo com o cristianismo. É claro que eu não sei o quanto o trabalho do professor Gadotti do Gadotti - porque eu não conheço, a menos que seja algum trabalho que eu li e não percebi que tivesse essa conotação - tinha que ver essa origem. Mas o que me preocupou na ocasião foi a pobreza do ponto de partida. O que nós fizemos aqui não tem, naturalmente, os vínculos de classes e rebeldia que poderiam caracterizar o PT. 


\section{Luiz de Sousa Junior: Por exemplo, professor.}

Florestan Fernandes: Por exemplo, a derrota da verba para a escola pública. Eu sofri quatro derrotas em todos os níveis, eu fui derrotado em todos os níveis na defesa desse princípio.

\section{Luiz de Sousa Junior: Comissão, subcomissões, comissão de sistematização e Plenário.}

Florestan Fernandes: Perdi em todos. O PSDB (Partido da Social Democracia Brasileira) já existia quando se fez a votação final no plenário. Eu apelei abertamente ao Covas (Mario Covas) que ele devia mudar a posição do partido. Ai, ele disse que não podia por conta do compromisso e eu disse "Até onde Vossa Excelência vai levar seus compromissos? Vossa Excelência saiu do PMDB (Partido do Movimento democrático Brasileiro), vai carregar o PMDB pelo resto da vida?". Mas são os compromissos típicos do político brasileiro que não pode negligenciar o significado das implicações eleitorais, políticas, de posições assumidas na elaboração exatamente dentro de uma Constituição. E tinha compromissos, como ainda tem, com aquele setor da escola confessional e é mais fechado. A Igreja hoje tem muitos pontos que não têm importância como teve (sic) no passado. E, de outro lado, há peculiaridades na história brasileira que são típicas do nosso país. Não têm nada que ver com a experiência alemã, com as experiências desse ou daquele país. Nós precisamos expandir o ensino e impedir essa dispersão de recursos que atingiu o ápice durante a ditadura militar. A escola concebida segundo o modelo das grandes empresas e os projetos querendo um financiamento e tinham a natureza de uma relação de pai para filho. E assim, muitos colégios se formaram em São Paulo, se transformaram em universidades e essas universidades hoje são poderosíssimas. E nasceram de empréstimos com juros muito baixos, outras no BNDES (Banco Nacional de Desenvolvimento Econômico e Social). Se o Estado investe nessa criação de escola, então ele deve investir na expansão e melhoria do seu próprio sistema. E é meu ponto de vista, por exemplo, eu tinha uma proposta que foi derrotada. E é claro que assim como o crescimento da escola privada depois da aprovação da Lei de Diretrizes e Bases que recebeu o nome do Carlos Lacerda, e das negociações que fizeram nesse projeto de 1962, o crescimento da escola privada foi muito rápido e sufocou o crescimento da escola pública. E eu conheci a situação de escolas privadas que não são especulativas, que não são mercantis, cobram, mas ensina (sic) cada fator e tem que ser também para a iniciativa privada. Esses setores são muito variados, nesses setores têm [sic] escolas muito ruins que foram criadas para facilitar os 
diplomas. Eu, por exemplo, conheci em São Paulo universidades que no fim de semana - a universidade estava construída a uns quarentas ou cinquentas metros de uma espécie de um imenso hotel com restaurantes -, era um fim de semana agradável, favorecia um fim de semana agradável. E essas escolas, naturalmente, teriam sucumbido. Agora, havia outros, como por exemplo a PUC (Pontifícia Universidade Católica) de São Paulo ou a PUC de Campinas, são escolas de qualidade, desenvolveram um padrão de ensino alto, criaram setores inventivos em diferentes áreas. Nós não podíamos sacrificar essas escolas, então eu fiz um artigo que previa a oficialização das escolas, salvo condições muito especiais. Eu enumerei um exame que eu faço de personalidade de instituições credenciadas para separar o joio do trigo. Mas, isso não passou, foi eliminado na subcomissão.

Luiz de Sousa Junior: Professor, no projeto do PT de constituinte que foi aprovado nessa reunião de Cajamar, estabeleceu-se que as escolas privadas funcionariam, obviamente, com certidão do Conselho Federal de Educação, mas elas teriam um prazo de dez anos para serem extintas. Ou seja, o projeto do PT defendia no fundo que todo ensino fosse estatal. $\mathrm{O}$ senhor concorda com isso?

Florestan Fernandes: Isso foi produto de uma concepção antagônica às correntes católicas. Não se sustentou no percurso por votação, que eu mencionei a você a respeito da norma pública para a escola pública, e não se sustentou. Agora, poderia ser uma saída. Eu não sou inimigo da escola privada, eu sou inimigo da escola privada de má qualidade, mercantil ou então que se proponha a um controle ideológico na formação das novas gerações.

\section{Luiz de Sousa Junior: Poderia existir uma escola privada sem nenhuma dessas conotações?}

Florestan Fernandes: Pode haver. Se não há, elas têm que se autocriticar. Eu não me coloquei como adversário da escola privada. Eu me coloquei como advogado da escola pública numa sociedade que tem as peculiaridades da sociedade brasileira. $\mathrm{Na}$ qual as elites dos estamentos que emergem mais tarde das classes dominantes, estamentos dominantes, de classes dominantes procuravam expandir a ignorância. Quer dizer, o futuro está na ignorância e não na igualdade de oportunidades educacionais. Os republicanos vieram com as ideias reveladoras nessa área, mas depois fizeram um acordo, os republicanos de 1870, com o Partido Republicano. Eles vieram com ideias inovadoras, mas para chegar ao poder tiveram que fazer acordos com os fazendeiros, as grandes empresas, os setores privados. 
E também com as famílias poderosas que não queriam ver adiante um processo de desnivelamento social por meio da competição. São Paulo foi uma área que na qual o ensino sofria uma forte influência norte americana e tinha como objeto uma educação capaz de ser um fator revolucionário dentro da sociedade. O Anísio estuda bem isso no livro dele Educação não é privilégio e em outras obras. Mas, esse pessoal, os educadores que defenderam essas doutrinas falaram no vácuo, porque a nossa escola pública na essência ela também é confessional, ela também é católica. E por causa dos professores, por causa dos estudantes, a família, aquela mentalidade arreigada, já basta isso para fechar a escola dentro um circuito, já basta isso para deixar a escola muito forte, não é brincadeira. É uma condição popular arraigada que se bate sobre experiências que pequenos grupos de educadores poderiam exercer. De outro lado, o ensino médio tinha uma alta qualidade, os ginásios do Estado possuíam um nível comparado ao ensino médio da França, da Inglaterra, era sólido. O professor que fazia concurso na Politécnica poderia depois ser aproveitado no ensino dessa escola, a escola normal. E o ginásio do Estado tinha forte qualidade mas, em seguida, na medida em que se abriram para uma massa maior de estudantada, as famílias transferiam seus filhos para escolas mais conservadoras, na maioria católica. Ainda assim, a marcha, a tendência do desenvolvimento de ensino é de crescimento maciço do ensino primário sob a responsabilidade do Estado. Havia mais ofertas e vagas nas escolas de ensino médio nas públicas do que nas privadas. E praticamente uma predominância do Estado no ensino superior. Essa situação se inverte especialmente no ensino médio, praticamente quase no mesmo nível quantitativo. E, nas universidades, o setor privado acabou alcançando uma maioria expressiva. Isso é produto da Lei de Diretrizes e Bases que nasceu no grupo dos educadores católicos e que tomou o nome de Carlos Lacerda, que apresentou o projeto no nome dele, e o governo Jânio, nesse ponto, aí traiu os seus livros e o seu nacionalismo populista e permitiu que isso acontecesse. A partir daí, o ensino médio vai crescer e o ensino superior idem no setor privado. Com os militares, esse desequilíbrio vai se tornando muito mais intenso por causa dos métodos de financiamentos e das concepções que vieram dos Estados Unidos com as comissões MEC/USAID impostas por círculos de educadores ou técnicos brasileiros e círculos de educadores ou técnicos americanos. E, a partir daí, surgem dois decretos de Castelo Branco que advogam desenvolvimento do ensino na direção de que a educação é um bem inestimável e que o estudante que não paga a escola, especialmente se ele for estudante do ensino superior, não sabe o valor da educação. É a mesma coisa que dizer que burro que come capim no campo não sabe avaliar o significado do milho (risos). 


\section{Luiz de Sousa Junior: Professor, é o seguinte... (interrupção)}

Florestan Fernandes: Eu estou encaminhando bem?

Luiz de Sousa Junior: Está. Eu acho que o senhor nesse último momento agora fez uma pequena digressão sobre a ações quanto ao ensino, eu acho que foi importante para dar um subsídio...

Florestan Fernandes: A minha intenção era mostrar que os constituintes que tinham vínculos com o pensamento pedagógico de esquerda atuaram em função de oportunidades e de necessidades comuns. Quer dizer que, eles se libertaram um pouco dos documentos de seus partidos. Os próprios partidos tinham que ser flexíveis e resultava uma espécie de oportunismo construtivo para obter vantagens. Porque se tomassem posições rígidas, aí haveria uma derrota geral. E se tomando posições flexíveis era possível introduzir coisas e avançar...

Veja bem o significado disso, o valor do capital, definido em termos da sua função social na forma de propriedade tanto no setor industrial quanto no setor agroindustrial, é uma vantagem e houve várias outras na mesma direção. Numa posição flexível, não que não teria um avanço, mas que pode servir de patamar para outros avanços posteriores. Então, eu poderia dizer a posição de cada um dos meus colegas da subcomissão, na área da educação. Mas, eu acho melhor não fazer, inclusive, poderia ser comprometedor com alguns. De fato, nós pescávamos em águas turvas, mas o resultado foi que o conteúdo dessa Constituição de 1988, no que se refere a educação, é o mais rico que nós já tivemos.

Luiz de Sousa Junior: Essa é a sua avaliação?

Florestan Fernandes: É.

Luiz de Sousa Junior: ...é uma declaração de educação eminentemente progressista?

Florestan Fernandes: É. Ela avançou, tanto que estão querendo "folgar". 
Luiz de Sousa Junior: É exatamente isso que queria perguntar ao senhor. Porque há um setor de esquerda, inclusive dentro do PT, que diz o seguinte "olha, na Constituinte o que aconteceu, nós ganhamos no varejo e perdemos no atacado".

Florestan Fernandes: Essa é uma ideia primária, porque você não ganha no varejo e perde no atacado ou ganha do atacado e perde no varejo. Ou você consegue impor concepções socialistas ou você sofre uma derrota relativa, não há varejos e atacados.

\section{Luiz de Sousa Junior: Mas, em compensação, o PT não quis assinar essa Constituinte que o senhor considera democrática ou progressista.}

Florestan: O caráter progressista ficou desligado do caráter socialista, a reforma ficou praticamente uma reforma burguesa do ensino público. Nós não tivemos muitas reformas. $\mathrm{O}$ capitalismo permite muitas e exige reformas e revoluções no seu desenrolar. Como eu falei, o socialismo, na sua formação e desenvolvimento, retomou várias evoluções e reformas sucessivas: revolução urbana, a reforma agrária, incialmente a reforma do Estado, a reforma educacional e por aí afora. Por isso que Marx e Engels na carta aos comunistas alemãs fala na revolução ininterrupta. De modo que o avanço que nós conquistamos aqui na área de educação é tipicamente de uma reforma educacional burguesa. Seria um contrassenso e desonesto afirmar que nós conseguimos introduzir dentro da Constituição qualquer plano socialista de ensino público ou de educação institucionalizada. É preciso deixar isso muito claro, muitos companheiros ficam com a ilusão que vão fazer a revolução dentro do parlamento, não é no parlamento que se faz revolução, é na sociedade civil, que pode se conjugar ao parlamento, às forças armadas e às outras instituições. E a minha posição é muito clara: nós não tínhamos um patamar sequer para universalizar o ensino primário, os diferentes ramos do ensino médio e do ensino superior. E a Constituição representou uma conquista de vários campos que antes não se incorporavam à Constituição ou então estavam abafados pela preponderância exclusiva do favorecimento dos alunos das famílias das classes dominantes. Quer dizer, o avanço se deu em democratizar as oportunidades educacionais, descentralizar tanto quanto possível a administração das escolas, ver a escola como uma instituição vinculada ao seu meio imediato. Há várias conquistas nessa direção, que inclusive foram ampliadas na Lei de Diretrizes e Bases, mais na primeira versão, muito menos na segunda. E ninguém sabe o que vai acontecer no Senado. 
Luiz de Sousa Junior: Se houver a revisão Constitucional, o senhor acha que o PT deve defender e entender de educação do que já foi aprovado? Ou o senhor acha que deve apresentar propostas mais radicais?

Florestan Fernandes: O PT sempre deve apresentar propostas mais radicais, porque é uma técnica legal da esquerda apresentar as propostas radicais e revolucionários. Depende do clima histórico. E na situação brasileira isso é imperativo para conquistar maiores espaços nas negociações. Se você partir de um patamar muito baixo, você praticamente fica com o prato de lentilhas que lhe é oferecido. Por isso que a posição do PT tem que ser de um partido com um só pensamento, comprometido com as classes trabalhadoras e com os oprimidos. Tem várias tendências que se circulam dentro do PT e todas elas estabelecem ganhos e diretrizes para que o PT não só se identificasse como um partido de classe, mas um partido de luta de classe e de revolução social.

\section{Luiz de Sousa Junior: O senhor confia no PT? É isso?}

Florestan Fernandes: Não é a questão de confiar ou não confiar. Eu não vejo nenhuma alternativa. Qual é a alternativa que você no cenário brasileiro além do PT? Eu acho que seria ótimo a gente contar com um partido operário revolucionário que agisse de uma forma congruente com as suas tarefas imediatas e dever de casa. Mas, mesmo como um partido que é populista nas suas relações com as massas e que é um partido que faz transações com as classes dominantes, e mesmo assim você encontra dificuldades para avançar. Eu ainda agora, ainda hoje, na reunião da tarde, vi uma fotografia provocante do Lula escrito em baixo "Lula, novo Lênin?”. Quer dizer, nós temos muitos obstáculos a enfrentar e o patamar do qual nós partimos exige que nós tenhamos uma posição realista. O próprio Marx, nessa perspectiva, foi participar de uma revolução burguesa. Ele ingressou na Alemanha defendendo uma revolução burguesa. O Marx como publicista desse governo e Engels como guerreiro, ele era muito formado nos militares, nas táticas militares. Por isso, nós não podemos negligenciar oportunidades históricas que são na sua origem muito modestas, mas que podem germinar e crescer. Isso pressupõe uma mobilização permanente e outra de autodefesa e de alerta no ataque, não perder as oportunidades que são desejáveis e não perder as oportunidades que permitem alcançar tarefas que são mais complexas. $\mathrm{Na}$ educação isso fica muito claro, eu acho que a educação é até um campo no qual se pode dar um dos exemplos mais característicos do que ocorrem na relação entre o PT e a sociedade brasileira. 